\title{
Learning Approach and Soft-skills Contribution toward Mathematical Higher Order Thinking Skill of Junior High School Students
}

\author{
Ani Minarni*, E. Elvis Napitupulu \\ Department of Mathematics FMIPA Unimed, Medan, Indonesia \\ *Corresponding author: animinarni10@gmail.com
}

Received October 18, 2019; Revised November 24, 2019; Accepted December 09, 2019

\begin{abstract}
Life skills such as social skill and emotional quotient recognized as soft-skills. Indonesian students softskills such as generous and helpful tends to decrease time to time which considered to threat nation character. Meanwhile, many researchers reported soft-skills is a dominant factor to determine one successfulness in life. Moreover, many hypothesize that it contributes much on mathematical higher-order thinking skills (MHOTS). Therefore, this research took place to help students keep and enhance their aspects of soft-skills. This quasi-experiment research applied constructivism-based learning at a public junior high school. Instruments used to collect data on soft-skills were questionnaire, interview, and observation. An essay test was administered to get data on students MHOTS. The data then analyzed using t-test and variance analysis. The findings showed that: (1) Learning approach contribute significantly toward student mathematical high order thinking skills as much as $57.4 \%$. Constructivism learning approach gives more influence to the students student mathematical high order thinking skills than direct instruction, (2) Student soft-skills contributed only $29.9 \%$ (categorize low) toward mathematical high order thinking skills. However, student soft-skills in the guided discovery classroom is better than its counterpart in the direct instruction classroom, (3) Learning approach and soft-skills simultaneously influence significantly toward student mathematical high order thinking skills. Therefore, it is recommended that teachers not only focus on the cognitive development of students but must care about the development of affective aspects as well.
\end{abstract}

\section{Keywords: learning approach, guided discovery learning, MHOTS, soft-skills}

Cite This Article: Ani Minarni, and E. Elvis Napitupulu, "Learning Approach and Soft-skills Contribution toward Mathematical Higher Order Thinking Skill of Junior High School Students." American Journal of Educational Research, vol. 7, no. 12 (2019): 925-929. doi: 10.12691/education-7-12-5.

\section{Introduction}

High order thinking skills (HOTS) constitutes higherorder thinking abilities such as analyze, evaluate, and synthesize. HOTS involves the ability to conclude on a complex problem, to think critically and creatively, to solve a problem, and metacognitive skills. The thinking abilities potentially active when one face an unfamiliar problem, uncertain, rise a dilemma or contradiction or question. HOTS that runs successfully spawns a valid product in the context of existing knowledge and experience. It fertilizes the growth of other intellectual skills continuously. HOTS is more difficult either to learn or to teach, but more worthy for it helps and enables one face various new problems need to solve.

Indonesian latest curriculum emphasizes that students should grasp conceptual understanding, reasoning, problem solving, and communication, which are HOTS, trough learning mathematics. HOTS related to mathematics recognized as mathematical high order thinking skills (MHOTS) [1]. Some of the MHOTS develop simultaneously. As an example, when a student solves a mathematical problem, he builds a new mathematical conceptual understanding, reasoning, connection, communication, and representation [2].

The fact recently shows Indonesian junior high school students are lack of mathematical conceptual understanding as well as mathematical representation and mathematical reasoning, as main components of MHOTS [2,3,4,5]. The lack of students MHOTS strongly guessed due to the instruction factor used in the classroom. Some researchers found direct instruction still dominate Indonesian mathematics classrooms [5,6]. Direct instruction gives less chance for students to actively engaging in the thinking process which cultivating reasonin [7]. Meanwhile, Napitupulu et al, and Saragih, et al reported that student-centered such as constructivismbased learning enables improving students MHOTS.

Along with cognitive aspect, 2013-Curriculum also mentioned that teachers should develop student affective aspects through constructivism-based learning. The importance arises especially since Indonesian student 
soft-skills, specifically social skill, emotional quotient, and attitude toward mathematics is less adequate $[8,9,10]$. On the other side, research result noted that soft-skills is a life skill, which is equally important to technical skill as well as cognitive aspect [11,12]. Even [13] stated 75\% of successful job is determined by soft-skills and technical skill only contributes $25 \%$.

However, the research result indicated that the students inadequate MHOTS and soft-skill could still be ameliorated by conducting constructivism-based instruction. Learning approach that based on constructivism used in this research is guided discovery learning. This study intended to investigate the simultaneous contribution of learning approach and student soft-skills toward the improvement of student MHOTS.

\section{Theoretical Framework}

\subsection{Mathematical High Order Thinking Skills}

In the era of the industrial revolution 4.0 like today, high order thinking skills are needed because this era is surrounded with big data that required to analyse carefully and used analysis results wisely. Higher-order thinking involves the learning of complex judgmental skills such as critical thinking and problem solving. Higher-order thinking is more difficult to learn or teach but also more valuable because such skills are more likely to be usable in novel situations (i.e., situations other than those in which the skill was learned) [14].

It is a notion that students must master the lower level skills before they can engage in higher-order thinking. However, the United States National Research Council objected to this line of reasoning, saying that cognitive research challenges that assumption, and that higher-order thinking is important even in elementary school [7].

Advocates of traditional education object to elevating HOTS above direct instruction of basic skills. Many forms of education reform, such as inquiry-based science, reform mathematics and whole language emphasize HOTS to solve problems and learn, sometimes deliberately omitting direct instruction of traditional methods, facts, or knowledge. HOTS assumes standards based assessments that use open-response items instead of multiple choice questions, and hence require higher-order analysis and writing.

It can be concluded from the opinion [7] that HOTS includes critical thinking, logical, reflective, metacognitive, problem solving, and creative thinking. The ability to think has the potential to be active when someone faces a problem that is unfamiliar to him, uncertain, creates a dilemma or invites questions. HOTS that runs successfully produces valid explanations, decisions, performance series, and products in the context of existing experience and knowledge and it fosters the continued growth of other intellectual skills. HOTS is rooted in the skills to apply and analyze knowledge simply and cognitive strategies that are intertwined with prior knowledge. Learning strategies and suitable learning environments are facilities for the growth of HOTS along with the growth of accuracy, self-supervision, openness, and flexible attitudes in students. This definition is in line with the currently developing theories relating to how HOTS is studied and developed in students.

A valid assessment of HOTS is inseparable from assignments that have an unfamiliar nature for students, at least they have never encountered. The format for measuring HOTS effectively is through questions that require students to show their performance [15], a kind of essay test. HOTS for mathematics can be called mathematical high order thinking skills [16] stated that the characteristics of HOTS proposed by Resnick are quite suitable for designing problem solving problems which are one type of HOTS. This characteristic can also be used to design questions that are designed in the interest of measuring students' MHOTS.

\subsection{Soft Skills}

Research shows that $75 \%$ of success in work is determined by soft skills and only $25 \%$ contributes technical skills (Sinha, 2008). Soft skills are as important as technical skills and cognitive aspects of a person $[11,12]$. Facts on the ground show that Indonesian students' soft skills are still low [9]. Soft skills, also called life skills, are the ability to behave in an adaptive and positive manner that enables humans to deal effectively with the demands and challenges of everyday life. Life skills are also referred to as psychosocial competencies, which are a set of human skills acquired through teaching or direct experience that is used to deal with problems and questions commonly encountered in everyday human life. Life skills are skills that function for the welfare of individuals and help individuals to develop into active and productive members of society.

More specific definition, soft skills are a combination of interpersonal skills, social skills, communication skills, character, attitudes, job demands, and emotional intelligence that allows one to direct the environment according to their needs, work together with others, show excellent performance, and achieve his goals through hard work. On the other hand, [17] defines soft skills as qualities that do not depend on knowledge (knowledge), which must be owned by someone to get the job he wants; include common sense, the ability to interact with others, as well as being supple positive.

\subsection{Guided Discovery Learning}

According to the Ministry of Education and Culture document, the Discovery Learning method is a learning theory that is defined as a learning process that occurs when the materials (subject matter) is not given to the students in the final form, but they are expected to organize themselves [1]. This is in line with the idea of [18], that: "Discovery Learning can be defined as the learning that takes place when the student is not presented with subject matter in the final form, but rather is required to organize it himself". The basis of Bruner's idea is the opinion of Piaget which states that children must play an active role in learning in the classroom.

Bruner uses a method called discovery learning, in which students organize the material learned with a final form. Discovery learning method emphasizes the 
importance of understanding concepts, meanings, and relationships, through an intuitive process to finally arrive at a conclusion. Discovery occurs when individuals are involved in mental processes to find several concepts and principles. This is done through observation, classification, measurement, prediction, determination and inference. Thus, discovery learning is the mental process of assimilation and principles in the mind.

As a learning strategy, discovery learning holds the same principles as inquiry (inquiry) and problem solving. There are no principal differences in the three types of learning, but in discovery learning the emphasis is more on finding concepts or principles that were previously unknown. From the problem side, the difference between discovery learning and inquiry is that in discovery learning the problems faced by students are problems that are engineered by the teacher, whereas in inquiry the problem is not the result of engineering, so students must exert all their thoughts and skills to get the findings in the problem is through the research process.

\section{Research Method}

The study is a quasi-experiment in nature. The population is the students of a public junior high school in Medan, Indonesia. It took Grade VIII-A to be the experimental class and Grade VIII-B to be the control one. Each classroom consists of thirty students.

An essay test on problem solving was held to capture data on MHOTS. The mathematical problems proposed were non-routine designed to foster the students perform their competencies in reasoning, critical thinking, and reflecting. Data on the student soft-skill was obtained through questionnaire, interview, and observation. The following are some statements in the questionnaire.

1. I am enthusiastically engage working together to make house environment clean.

2. I am able working in-group to complete mathematics task and other lesson.

3. I appreciate peer opinion in-group discussion.

Some examples of observation guidance item are list below.

1. The students engage actively working in group.

2. The students persevere in working on tasks attacking mathematics problem.

3. The students interact either with peer or with teacher flexibly and fluently.

Some examples of questions in interview are listed below.

1. Are you available to help a friend who encounters barriers in understanding a lesson?

2. Do you have difficulties to express your idea to others in the classroom?

3. Do you enjoy discussing and working together with other?

Learning approach used in the experimental class was guided discovery. The syntaxes of the approach constitute:

a. Teacher describe the topic to learn, deliver the learning objectives, motivate the students, and explain the activities related to the lesson.

b. Teacher pose a problem and questions related to the topic to learn. c. Each group formulate hypothesis and design an experiment or learn experimental steps explained in student work sheet (SWS), by the teacher, or in the textbook.

d. Teacher guide the students when formulating a hypothesis and planning an experiment.

e. Teacher facilitates the groups to conduct the experiment.

f. Each group conduct an experiment or an observation to collect data needed to test the hypothesis.

g. Each group organizes and analyzes data and make a report on the result of the experiment or the observation.

h. One group presents its experimental result and propose concept discovered. Teacher guide the students in constructing the concept based on the investigation.

Meanwhile, in the control class teacher conducted the lesson using direct instruction. This learning approach typically teacher-centered. The teacher functions as the source of knowledge and transfer the knowledge to the students.

Either in the experimental class or in the control, the teacher used SWS during conducting the lesson. The students work in group to attack three up to four problems in the SWS. The SWS differs in its design. The first was designed appropriately to the syntaxes of discovery learning, the second was designed hierarchically corresponding to the topics presented in the textbook from the government. The materials delivered in the research was statistics. After studying the statistics students are expected be able to solve problems related to central data measure and be able to present data in various ways, such as graph, diagram, table. The problems given to the students to work on are presented below.

\section{Problems:}

1. Determine the average of odd numbers less than 60 .

2. Observe the distribution of student score on mathematics test in the table below. Determine the value of $x$ if the average score is 70.25 .

Table 1. Students Score in Mathematical Test

\begin{tabular}{|c|c|}
\hline Score interval $(\boldsymbol{x})$ & Category \\
\hline $0-20$ & 5 \\
\hline $21-40$ & $\mathrm{X}$ \\
\hline $41-60$ & 35 \\
\hline $61-80$ & 25 \\
\hline $81-100$ & 10 \\
\hline
\end{tabular}

Students is said to have achieved MHOTS if he performs well in solving mathematical problems. The indicators of solving MHOTS in the research consist of:

1. Understanding the problem

2. Applying reasoning to attack the problem (to pose conjecture and proof it)

3. Applying strategies

4. Conclude the result obtain

Understanding problem step includes the ability to represent the problem into various forms up to modeling [2]. While applying strategy covers executing the strategy up to find the solution.

To be called having good soft-skills, the students should fulfil the aspect listed below. 
1. Be able to recognize self-emotion and others'.

2. Be able to manage self-emotion

3. The ability to motivate himself

4. Have self-regulated learning

5.The ability to communicate and develop relationship

The researchers then derived the aspects into forty items of statement in the questionnaire. Having had the result, they will be categorized into three level of soft-skill, i.e. good, moderate, and poor as mentioned in Table 2. Each item offers four options. Thus, the ideal score is 160 .

Table 2. Soft Skills Grouping

\begin{tabular}{|c|c|}
\hline Score interval $(\mathrm{x})$ & Category \\
\hline $110 \leq \mathrm{x}<160$ & Good \\
\hline $80 \leq \mathrm{x}<110$ & Moderate \\
\hline $\mathrm{x}<80$ & Poor \\
\hline
\end{tabular}

The hypothesis to be tested are:

(1) Learning approach contribute significantly to students MHOTS achievement.

(2) Student soft-skills contribute significantly to students MHOTS achievement.

(3) Learning factor and students soft-skills simultaneously contribute significantly to students MHOTS achievement.

The study used analysis of variance to see the contribution of learning factor and student softs-kills toward MHOTS. Meanwhile, t-test was used to see the difference in student soft-skill based on learning factor [19].

\section{Results and Discusion}

Statistical test result of learning approach influence towards student MHOTS and soft-skills was presented in Table 3.

Table 3. Test of between-Subjects effect

\begin{tabular}{|c|l|c|c|c|c|c|}
\hline No. & Source & Type III SS & Df & MS & F & Sig. \\
\hline 1 & Corrected Mode & $218.771^{\mathrm{a}}$ & 5 & 43.754 & 14.578 & .000 \\
\hline 2 & Intercept & 8938.453 & 1 & 8938.453 & 2978.025 & .000 \\
\hline 3 & Approach & 132.945 & 1 & 132.945 & 44.293 & .000 \\
\hline 4 & Soft-skills & 76.810 & 2 & 38.405 & 12.795 & .000 \\
\hline 5 & App*Soft-skills & 3.944 & 2 & 1.972 & .657 & .523 \\
\hline 6 & Error & 162.079 & 54 & 3.001 & & \\
\hline 7 & Total & 9681.000 & 60 & & & \\
\hline 8 & Corrected Total & 380.850 & 59 & & & \\
\hline
\end{tabular}

R-square: .57.

From Table 3 we concluded that learning factor influence significantly on student MHOTS. Moreover, the interaction between learning factor and soft-skills is significant such that both factors effect simultaneously on MHOTS achievement. It means that MHOTS achievement is not parallel to the soft-skills; high soft-skills might not be followed by high MHOTS. We can also observe that the learning factor contributed $57 \%$ to the MHOTS. Guided discovery approach effected better to the student MHOTS achievement than direct instruction did. The difference score of MHOTS test between both classes is presented in Table 4.
Table 4. Independent samples t-test for MHOTS

\begin{tabular}{|c|c|c|c|c|}
\hline $\mathrm{T}$ & Df & Sig. & Mean diff. & Std. error diff. \\
\hline 5.742 & 58 & 0.000 & 3.033 & .523 \\
\hline
\end{tabular}

From Table 4, we again concluded guided discovery learning approach (experiment class) better influences on student MHOTS achievement than direct instruction (control class). The student score in this class is 3.033 points higher than the one in the control class (with ideal score 20). Next, the result of grouping soft-skills factor in both class is presented in Table 5 .

Table 5. Grouping of Students Soft Skills

\begin{tabular}{|l|c|c|c|}
\hline \multirow{2}{*}{ Score interval $(x)$} & \multirow{2}{*}{ Category } & \multicolumn{2}{|c|}{ Frequency } \\
\cline { 3 - 4 } & & Control & Exp. \\
\hline $110 \leq x<160$ & Good & 2 & 11 \\
\hline $80 \leq x<110$ & Moderate & 28 & 19 \\
\hline$x<80$ & Poor & 0 & 0 \\
\hline
\end{tabular}

After having had implemented the instruction, from Table 5, we see the majority of the student soft-skill categorized moderate. The result was contrast to the fact before implementing the instruction, which is poor. Moreover, the difference in learning factor implies to the difference of student soft-skill in experimental and control class. The difference is depicted in Table 6.

Table 6. Independent samples t-test for Soft Skills

\begin{tabular}{|c|c|c|c|c|}
\hline $\mathrm{T}$ & $\mathrm{Df}$ & Sig. & Mean diff. & Std. error diff. \\
\hline 4.171 & 58 & 0.000 & 11.633 & 2.649 \\
\hline
\end{tabular}

By seeing Table 6, we concluded guided discovery learning approach gives better influence toward student soft-skill than the direct instruction did. The achievement differs at amount 11.633 from ideal score 160 (since the scale is consisted 40 statements with 4 Likert scale).

The contribution of Soft Skills towards MHOTS is displayed in Table 7.

Table 7. Soft Skills Contribution towards MHOTS

\begin{tabular}{|c|c|c|c|c|}
\hline \multicolumn{5}{|c|}{ Summary } \\
\hline Soft skills & R & R Square & Adjusted R Square & Std. Error \\
\hline 1 & $.299^{\mathrm{a}}$ & .089 & .074 & 2.445 \\
\hline
\end{tabular}

We see in Table 7 that soft skills gives low contribution towards MHOTS of the students, it is only $29.9 \%$.

The low contribution of soft-skills toward MHOTS achievement in this study is not in line with the statement proposed by Sinha [13] as well as John [11] and Zher [12] The last two writers stated that cognitive and affective have equal importance to academic successfulness, whereas Sinha emphasize more than half. The incompatibility of the results of this study with previous studies may be due to inadequate samples taken. It might necessary to take greater sample such that the result more representative. It seems natural and objective if affective aspect contribute more to the academic achievement than cognitive. Many believe that the soft-skill aspects such as perseverance, not to easily give up while struggling in an effort attacking a problem, flexible in human-interaction, or other aspects of affective are conditions for one's 
success. It was Albert Einstein asserted that talent contribute only $10 \%$ while the rest lay on work hard, which the main aspect of soft-skills.

Overall, from output of statistical test presented in Table 3, we see that learning factor influence significantly on MHOTS achievement and student soft-skills. In accordance with the hypothesis proposed, the result of the test revealed the student MHOTS and soft-skills in the experimental is higher than in the control class. The result is in line with the effort deployed in the experimental class which using guided discovery. In the classroom the teacher trained the student to become a problem solver where solving a problem is the core element of MHOTS. While in the control class, teacher did not particularly give chance to the students to solve mathematical problems themselves. The teacher only demonstrated solving mathematical problem before his students and did not force them to grasp the ability themselves. The learning process takes priority to acquire factual knowledge as much as possible such as [20] and [16] reported.

Solving mathematical problems activities demands the students to deploy their proficiency in the affective domain such as social skill and emotional quotient. They are to perform perseverance, persistence, not to give up, and flexibility in interacting and building relationship with others while working collaboratively attacking the mathematical problems in hand. They are also asked to be able to manage their emotion and to motivate either themselves or the members of group to seek the solution of the problem. The problem solving activities, which repeated from one lesson to the next, gradually formed their habit and finally character. Those activities enable students soft-skill improved after having had instructed through guided discovery learning approach.

It can be concluded based on Table 3, row number 5 that learning approach and soft skills simultaneously influence significantly to student MHOTS achievement, that is, it is possible for students who have low soft skills to get high MHOTS score test, conversely students who have high soft skills might get low MHOTS test scores. Larger samples are needed to get more robust contributions from learning approaches and soft skills towards MHOTS.

\section{Conclusion}

1) Learning approach contribute significantly toward student mathematical high order thinking skills as much as 57.4\%. Constructivism learning approach gives more influence to the students mathematical high order thinking skills than direct instruction.

2) Student soft-skills contributed only $29.9 \%$ (categorize low) toward mathematical high order thinking skills. However, student soft-skills in the guided discovery classroom is better than its counterpart in the direct instruction classroom.
3) Learning approach and soft-skills simultaneously influence significantly toward student mathematical high order thinking skills.

\section{References}

[1] Indonesian Memorandum of Education 2013.

[2] Minarni, A., Napitupulu, E. E., Husein, R. (2016). Mathematical Understanding and Representation Ability of Public Junior High School in North Sumatera. Journal on Mathematics Education, 7(1), 45-56.

[3] Efil, J.P., Minarni, A., Sitompul, P. (2018). The Effect of Concept Mapping and Microsoft Visio-Assisted Cooperative Learning Model towards Mathematical Conceptual Understanding and Emotional Intelligence of Junior High School Students. IOSR Journal of Research \& Method in Education, 8 (3), 59-64.

[4] Mullis, et al. (2012). TIMSS 2011 International Results in Mathematics. TIMSS \& PIRLS International Study Center Lynch School of Education, Boston College.

[5] Napitupulu, E., E., Suryadi, D., Kusumah, Y., S. (2016). Cultivating Upper Secondary Students’ Mathematical Reasoning Ability and Attitude towards Mathematics through Problem-Based Learning. Journal on Mathematics Education, 7(2), 61-71.

[6] Saragih, S., \& Napitupulu, E., Fauzi, A. (2017). Developing Learning Model Based on Local Culture and Instrument for Mathematical High Order Thinking Ability. International Educational Studies, 10(6).

[7] Minarni, A. (2013). Pengaruh Pembelajaran Berbasis Masalah terhadap Kemampuan Pemahaman Matematis dan Keterampilan Sosial Siswa SMP di Kota Bandung. Jurnal Paradikma, 6(2), 162-174.

[8] Minarni, A. (2017). On Eight Grade Students Understanding in Solving Mathematical Problems. Vol. 13, No. 12; 2017.

[9] Murni, A. (2013). Peningkatan Kemampuan Pemecahan Masalah dan Representasi Matematis Siswa SMP melalui Pembelajaran Metakognitif Berbasis Soft-skills. Disertation. Bandung: PPs UPI.

[10] Napitupulu, E., E. (2011). Pengaruh Pembelajaran Berbasis Masalah terhadap Kemampuan Penalaran, Pemecahan Masalah Matematis, dan Sikap Siswa terhadap Matematika. Disertation. Bandung: PPs UPI.

[11] John, J. (2009). Study on the Nature of Impact of Soft Skills Training Programme on the Soft Skills Development of Management Students. Pacific Business Review, 19-27.

[12] Zehr, M. A. (1998). New office economy putting greater demands on schools. Education Week, 17(23).

[13] Sinha, M., P. (2008). Minding Our MBA Manners. Competition Success Review: ghrdc.org/articles/Minding our MBA Manner \& MBA Education

[14] Anderson, L.W. \& Krathwohl, D.R. (2001). A Taxonomy for Learning, Teaching, and Assessing. New York: Addison Wesley Longman, Inc.

[15] Kulm, G. (1993). Assessing high order thinking in mathematics. Washington, D.C: American Association for the Advancement of Science: AAAS Publication.

[16] Minarni, A., Napitupulu, E. E. (2017). Developing Instruction Materials Based on Joyful PBL to Improve Students Mathematical Representation Ability. International Education Studies, 10(9).

[17] Collins English Dictionary, (1988). Tersedia: https://www.collinsdictionary.com/dictionary/ english

[18] Bruner, J. S. (1961). The Act of Discovery. Harvard Educational Review, vol. 31. pp. 21-32.

[19] Glass, G. V., Hopkins, K. D. (1996). Statistical Methods in Education and Psychology, third edition. Pearson.

[20] Ronis, D., L. (2008). Problem-based Learning for Math \& Science; Integrating Inquiry and the Internet. California: Corwin Press. 